\title{
DNA Extraction from Bovine Mummified Fetuses and Detection of Factor XI Gene Deficiency in the Mummies
}

\author{
Mohamed Elshabrawy GHANEM ${ }^{1)}$, Masahide NISHIBORI'), \\ Toshihiko NAKAO ${ }^{1) \#}$ and Masaharu MORIYOSHI ${ }^{3)}$
}

\author{
1) Laboratory of Animal Science, Graduate School for International Development and \\ Cooperation, Hiroshima University, 1-5-1 Kagamiyama, Higashi-Hiroshima 739-8529, \\ ${ }^{2)}$ Laboratory of Animal Genetics, Graduate School of Biosphere Science, Hiroshima \\ University, 1-4-4 Kagamiyama, Higashi-Hiroshima 739-8528, ${ }^{3)}$ Division of Theriogenology, \\ School of Veterinary Medicine, Rakuno Gakuen University, Ebetsu, Hokkaido 069-8501, \\ Japan \\ \#Present: Laboratory of Theriogenology, Department of Veterinary Medicine, Faculty of \\ Agriculture, Yamaguchi University, Yoshida 1677-1, Yamaguchi, Japan
}

\begin{abstract}
Genomic DNA extracted from bovine mummified tissue is valuable material for detection of some genes that may contribute to fetal abnormalities. In this study bovine genomic DNA was extracted from the hardened tissue samples of ten bovine mummified fetuses. The amount of genomic DNA extracted from $2 g$ of the mummified tissues by the phenol/chloroform-ethanol method was low (less than $4 \mu \mathrm{g} / \mathrm{ml}$ ) for all samples. The extracted DNA was then amplified by the GenomiPhi ${ }^{\mathrm{TM}}$ DNA amplification system. After amplification, the amount of DNA was increased to more than $100 \mu \mathrm{g} / \mathrm{ml}$ for all samples. This amplification system was shown to be a good tool for amplifying the genomic DNA of the mummified fetuses. The amplified genomic DNA was used for testing the mummies for Factor XI gene deficiency, an autosomal recessive deficiency involved in the early stages of the intrinsic blood coagulation pathway. Exon 12 of the Factor XI gene of the mummies was amplified by PCR. Two of the ten mummified fetuses were heterozygous for the Factor XI gene as indicated by the presence of two amplified DNA fragments of $320 \mathrm{bp}$ and $244 \mathrm{bp}$. Factor XI deficiency has already been described in Holstein cattle. However, no report is available for bovine fetus. In this study, DNA was extracted and amplified from the bovine mummified fetuses, and the samples were successfully tested for Factor XI gene deficiency in the mummies.
\end{abstract}

Key words: DNA extraction, Factor XI gene deficiency, Mummified fetus

(J. Reprod. Dev. 51: 347-352, 2005)

$\mathbf{F}$ etal mummification does not occur in the first trimester of gestation because embryonic or fetal death prior to the development of the fetal bones is usually followed by absorption or

Accepted for publication: February 16, 2005

Published online: March 23, 2005

Correspondence: T. Nakao (e-mail address: tnakao@yamaguchiu.ac.jp) The first author was supported by the Egyptian Scholarship Program (Egyptian Ministry of Higher Education). resorption of the fetal and placental tissues [1]. Two types of fetal mummification have been reported in animals, the hematic type in cattle and the papyraceous type in other species. Jalakas [2] studied 19 cases of bovine mummification over several years and reported that all cases were of the hematic type.

Mummification of bovine fetuses occurs in cattle of all ages. It is observed most often in Guernsey 
cattle, although other breeds are also commonly affected [1]. Fetal mummification is rare in cattle, occurring in 0.13 to $1.8 \%$ of conceived animals [3]. Torsion of the umbilical cord and some infectious agents could cause fetal mummification in cattle [1]. In addition, genetic factors are involved in bovine fetal mummification [4]. Stevens and King [5] suggested that the abortion and fetal mummification, experienced in a Holstein herd at 120 to 180 days of gestation when the daughters of two popular sires were bred artificially by the other sire, were due to an autosomal recessive gene.

Nucleic acids preserved in bovine mummified tissues are valuable materials for the study of some genes that contribute to fetal abnormalities. Although mummified tissues are preserved for a long time, the integrity of nucleic acids for molecular biologic study still remains an issue. Several groups of researchers were able to extract DNA from mummified tissues [6,7]. It has been shown that more than $99 \%$ of DNA isolated from mummified tissues is chemically modified [7-9]. These changes made amplification of the nucleic acids very difficult. The mummified tissues contain inhibitors that inhibit PCR reaction [8], which added a significant difficulty to DNA amplification. The first objective of this study was to report a method for DNA extraction and amplification from bovine mummified fetuses.

Factor XI is a serine protease involved in the early stages of the intrinsic blood coagulation pathway [10]. Factor XI deficiency was first recognized in Holstein Friesian cattle in USA [11], while Gentry et al. [12] reported the first case of Factor XI deficiency in a steer in Canada. In Japan, Ghanem et al. (submitted for publication) reported the first case of Factor XI deficiency in Holstein cattle. Marron et al. [13] identified the mutation that caused Factor XI deficiency in cattle. The mutation consisted of a 76-base insertion into exon 12 , one of the coding regions of the Factor XI gene.

Carriers (heterozygotes) of the defective gene are outwardly normal, while affected animals (homozygotes) have a mild hemophilia-like disorder, and 25 percent of offsprings produced by mating a carrier bull to a carrier cow will be affected with Factor XI deficiency [14]. Unlike many other blood clotting disorders, Factor XI deficiency may or may not be accompanied by spontaneous or induced bleeding episodes. Continued bleeding from the umbilical cord is sometimes seen in affected calves. Furthermore, affected animals appear more susceptible to diseases, such as pneumonia, mastitis, and metritis [14]. Factor XI deficiency has been described in Holstein cattle. However, no report is available for bovine fetuses. Since we were interested in the presence of Factor XI gene deficiency in cattle, in addition to assessing the reliability of the extracted DNA from the mummies for PCR and sequencing, we tried to test the mummies for Factor XI gene deficiency. The second objective of this study was, therefore, to examine the bovine mummified fetuses for Factor XI gene deficiency.

\section{Materials and Methods}

\section{Mummified fetuses}

Ten bovine mummified fetuses were used in this study; nine cases were from the collection at the Department of Theriogenology, College of Veterinary Medicine, Rakuno Gakuen University, Japan. All the mummies had been fixed in 10\% formalin and then dried (Fig. 1). The case history of these fetuses was unknown. The ages of the fetuses were estimated by measuring the crown rump length [15] (Table 1). The other mummified fetus was diagnosed in a Holstein Friesian cow, and was expelled from the cow following treatment with prostaglandin $\mathrm{F}_{2 \alpha}$ (Cloprostenol $0.5 \mathrm{mg}$, intramuscularly) 5.5 months after insemination. The age of the fetus at the time of death was estimated to be 105 days. The fetus was fixed in $10 \%$ formalin, and preserved at the Laboratory of Animal Science, IDEC, Hiroshima University, Japan.

\section{Extraction of genomic DNA from mummified fetuses}

About $2 g$ of tissue was excised with a sterile sharp knife from the mummified fetuses, and was kept in sterile test tubes. Liquid nitrogen, 100 to 200 $\mathrm{ml}$, was added to the tissue sample in a clean mortar. The tissue samples were ground thoroughly. The ground powder was stored in a sterile $1.5 \mathrm{ml}$ Eppendorf tube. One hundred $\mathrm{mg}$ of the powder was put into a $2 \mathrm{ml}$ sterile tube, and 1.5 $\mathrm{ml}$ of $0.5 \mathrm{M}$ EDTA, $\mathrm{pH} 8.0$, was added. The mixture was incubated overnight at $55 \mathrm{C}$, and each tube was then washed with $1.5 \mathrm{ml}$ of distilled water and centrifuged at $12,000 \mathrm{rpm}$ for $3 \mathrm{~min}$. The supernatant solution was removed carefully. 


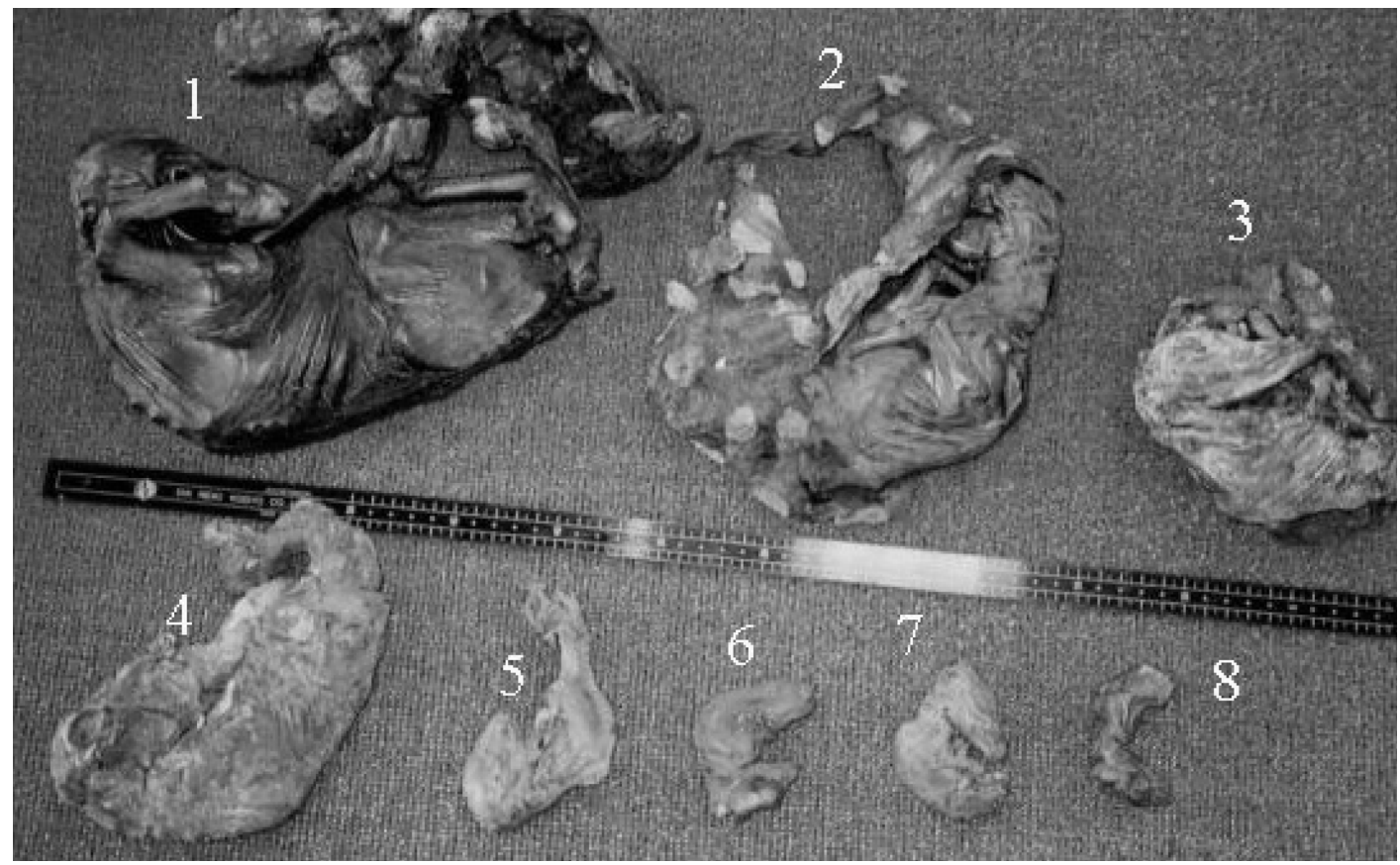

Fig. 1. Collections of bovine mummified fetuses used for DNA extraction and Factor XI gene analysis.

Table 1. Crown rump length (CRL) of the ten mummified fetuses under study in addition to the amount of genomic DNA extracted from $2 \mathrm{~g}$ of mummified tissue samples before and after using the GenomiPhi ${ }^{\mathrm{TM}}$ amplification system

\begin{tabular}{ccccc}
\hline Fetus & CRL $(\mathrm{mm})$ & Age (days) & $\begin{array}{c}\text { Amount of extracted DNA } \\
(\mu \mathrm{g} / \mathrm{ml})^{\dagger}\end{array}$ & $\begin{array}{c}\text { Amount of amplified DNA } \\
(\mu \mathrm{g} / \mathrm{ml})^{*}\end{array}$ \\
\hline 1 & 440 & 157 & 3.2 & 311.3 \\
2 & 280 & 123 & 2.5 & 385.3 \\
3 & 230 & 110 & 1.2 & 219.8 \\
4 & 370 & 142 & 1.5 & 109.9 \\
5 & 200 & 106 & 1.4 & 151.7 \\
6 & 170 & 100 & 1.8 & 235.8 \\
7 & 150 & 87 & 1.1 & 150.6 \\
8 & 100 & 70 & 1.7 & 268.2 \\
9 & 120 & 76 & 1.9 & 169.3 \\
10 & 190 & 105 & 2.2 & 315.2 \\
\hline
\end{tabular}

${ }^{\dagger}$ Extraction using the phenol/chloroform-ethanol method. ${ }^{*}$ Amplification using the GenomiPhi ${ }^{\mathrm{TM}} \mathrm{DNA}$ amplification system.

Washing and centrifugation were repeated three times to remove any EDTA solution. The sediment was kept in clean sterile $1.5 \mathrm{ml}$ Eppendorf tubes. Lysis buffer ( $50 \mathrm{mM}$ Tris- $\mathrm{HCl}, 0.1 \mathrm{M} \mathrm{NaCl}, 20 \mathrm{mM}$ EDTA, and 1\% SDS, pH 8.0) (360 $\mu \mathrm{l})$ and $40 \mu \mathrm{l}$ of proteinase $\mathrm{K}$ solution $(10 \mathrm{mg} / \mathrm{ml})$ were added to the tubes and mixed thoroughly with the sediment.
All the mixtures were incubated at $55 \mathrm{C}$ overnight. The genomic DNA of each fetus was extracted using the phenol/ chloroform-ethanol method [16]. The genomic DNA concentration was measured using a GeneQuant ${ }^{\mathrm{TM}}$ II spectrophotometer (Amersham Biosciences, NJ, USA) with a micro crystal cell. 


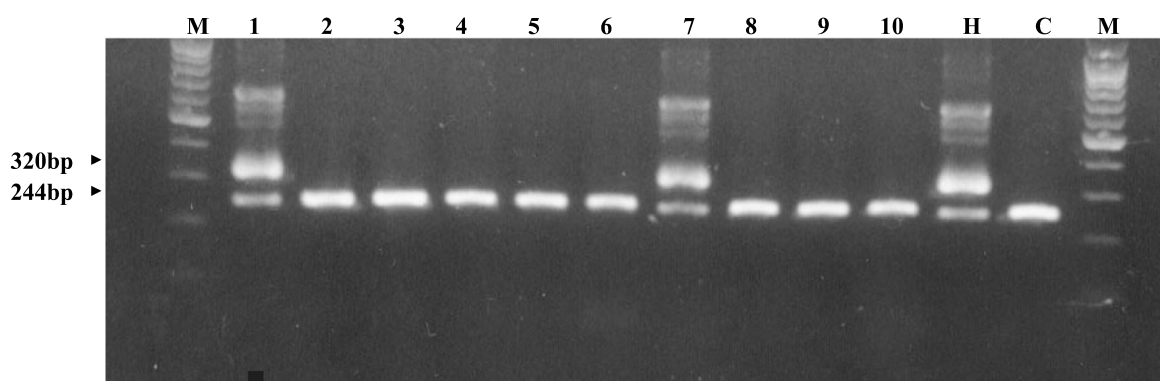

Fig. 2. PCR products of ten bovine mummified fetuses, a heterozygous cow $(\mathrm{H})$ and a control normal cow $(\mathrm{C})$ were analyzed by gel electrophoresis on $2 \%(\mathrm{w} / \mathrm{v})$ TBE agarose gel. Mummified fetuses Nos. 1 \& 7 were heterozygous for Factor XI gene, showing two DNA bands of $320 \mathrm{bp}$ and $244 \mathrm{bp}$, while the other fetuses were normal, showing only one DNA band of $244 \mathrm{bp}$. The ladder marker (M) was $100 \mathrm{bp}$.

\section{Amplification of fetal genomic DNA}

The extracted DNA of the fetuses was amplified using a GenomiPhi ${ }^{\mathrm{TM}}$ DNA amplification kit (Amersham Biosciences, NJ, USA). One $\mu$ l of the released DNA solution was added to a microfuge tube containing $9 \mu \mathrm{l}$ of sample buffer (random hexamer primers) and mixed thoroughly. The solution was heated up to $95 \mathrm{C}$ for $3 \mathrm{~min}$ and then cooled down to $4 \mathrm{C}$ on ice, allowing random priming of the hexamers. For each previous amplification reaction, $9 \mu \mathrm{l}$ of reaction buffer with 1 $\mu \mathrm{l}$ of enzyme were mixed on ice, and then added to the cooled sample. These reactions included Phi29 DNA polymerase, deoxynucleotide triphosphate, and buffer components optimized for linear DNA synthesis. The samples were incubated at $30 \mathrm{C}$ for 16-18 hours; during that time, the available nucleotides were consumed and converted into high molecular weight fragment copies of the input DNA. The samples were heated to $65 \mathrm{C}$ for $10 \mathrm{~min}$ and then cooled down to $4 \mathrm{C}$.

\section{DNA typing for the Factor XI gene}

Exon 12 of the Factor XI gene was amplified by PCR with Factor XI forward (5' CCC ACT GGC TAG GAA TCG TT) and Factor XI reverse (5' CAA GGC AAT GTC ATA TCC AC) primers (GenBank accession number, AY570504). The PCR reaction was performed in a total volume of $20 \mu \mathrm{l}$ containing $14.3 \mu \mathrm{l}$ of distilled water, $2 \mu \mathrm{l}$ of $10 \times$ PCR buffer, 2 $\mu \mathrm{l}$ of dNTPs (Applied Biosystems, Foster City, CA, USA), $0.4 \mu \mathrm{l}$ of each primer (20 nmol), $0.8 \mu \mathrm{l}$ of amplified genomic DNA, and $0.1 \mu \mathrm{l}$ of AmpliTaq Gold DNA polymerase (5 U/ $\mu$ ) (Applied Biosystems, Foster City, CA, USA). Samples were amplified for 34 cycles at the following temperatures: denaturation at $95 \mathrm{C}$ for $30 \mathrm{sec}$., annealing at $55 \mathrm{C}$ for $1 \mathrm{~min}$ and extension at $72 \mathrm{C}$ for $30 \mathrm{sec}$. PCR products were analyzed on $2 \%$ agarose gel with ethidium bromide in TBE buffer for $30 \mathrm{~min}$.

\section{DNA sequencing}

The PCR products from the mummified fetuses were purified and sequenced using the Big Dye terminator cycle sequencing procedure on an $\mathrm{ABI}$ PRISM 377 DNA Sequencer (Applied Biosystems, Foster City, CA, USA). The data was analyzed using Sequencing Analysis Software Version 3.3 (Applied Biosystems, Foster City, CA, USA).

\section{Results}

The amount of extracted DNA from the tissue samples of the mummified fetuses using the phenol/chloroform-ethanol method was less than 4 $\mu \mathrm{g} / \mathrm{ml}$. After DNA amplification with the GenomiPhi DNA amplification kit, the amount of DNA was increased to more than $100 \mu \mathrm{g}$ (Table 1).

Two of the mummies exhibited two bands of 244 $\mathrm{bp}$ and $320 \mathrm{bp}$, indicating that they were heterozygous (carriers) for the Factor XI gene deficiency. The remaining mummies showed DNA bands of $244 \mathrm{bp}$, indicating they were normal. The results of DNA typing of the mummies were compared with normal and heterozygous control cows (Fig. 2).

The sequence results for the mutant allele (320 $\mathrm{bp}$ ) of the heterozygous mummies revealed a 
mutation that consisted of a $76 \mathrm{bp}$ insertion, mainly sequences of poly-Adenine, with a terminal codon (TAA), while the normal allele (244 bp) showed normal DNA sequences.

\section{Discussion}

The cause of fetal mummification has yet to be elucidated. A number of causes, including genetic factors, might be involved [4]. Biochemical genetic diseases in dairy cattle transmitted as autosomal recessive traits can cause significant economic losses to the dairy industry. Since carrier animals do not exhibit clinical signs of the disease allowing for the detection, identification, and elimination of those affected animals from the breeding stock it is essential to prevent its dissemination to the next generation [14].

Today, DNA can be obtained from fossils, and the recovery of ancient DNA from a variety of samples and organisms is technically feasible [17]. Moreover, DNA has been isolated from fresh and formalin-fixed tissue of aborted bovine fetuses using proteinase $\mathrm{K}$ digestion followed by ethanol precipitation [18]. It may also be possible to extract DNA from the macerated fetus, although this has not been reported yet. This has opened a new window for research at the level of molecular history. Bovine mummification is rare [3], and, moreover, its exact causes are still obscure. Extraction and amplification of DNA from the mummies can help in identification of some of the unknown causes at the molecular level. We successfully extracted genomic DNA from mummies that had been stored, for a long period of time, as an educational collection after being fixed in formalin and dried. The DNA extracted from each sample was generally a small amount. A DNA amplification kit was used to increase the amount of template DNA of the fetuses. The GenomiPhi DNA amplification system utilizes bacteriophage Phi29 DNA polymerase to exponentially amplify double-strand linear DNA templates. Microgram quantities of DNA are generated from nanogram amounts of the starting material after an overnight incubation. DNA replication is accurate because of the proofreading activity of Phi29 DNA polymerase [19]. The amount of extracted DNA from $2 \mathrm{~g}$ of tissue from the mummified fetuses was less than $4 \mu \mathrm{g} / \mathrm{ml}$. After DNA amplification, the amount of DNA increased to $100 \mu \mathrm{g} / \mathrm{ml}$ or more.

Factor XI gene deficiency, which has so far been reported in cattle in different countries [10-12], was also detected in fetuses in this study. However, we were not able to examine whether this gene deficiency was derived originally from the dam or the sire of those fetuses. The mummies were from old collections donated from a number of veterinarians across the country, and the breeding history of the mummies was unknown.

Our results indicated that, for Factor XI gene deficiency, a normal fetus had a DNA fragment of $244 \mathrm{bp}$, while a heterozygous cow or fetus exhibited two DNA fragments of $320 \mathrm{bp}$ and $244 \mathrm{bp}$. The DNA sequence of the mutant allele was consistent with Marron et al. [13], who identified the mutation of Factor XI gene deficiency. The mutation consisted of a 76-base insertion into exon 12 . The insertion consisted of long strings of adenine (A) bases with a stop codon (TAA). In conclusion, we successfully extracted DNA from the mummified fetuses and detected Factor XI deficiency in the mummies. However, Factor XI deficiency detected in the mummified fetuses was not a factor causing the fetal mummification. Other genes, which may contribute to this condition, need to be investigated.

\section{Acknowledgment}

We would like to thank Dr. Masashi Akita of NOSAI Hiroshima for providing us with a mummified fetus collected at a commercial farm in Hiroshima Prefecture.

\section{References}

1. Roberts SJ. General observation of abortion. In: Roberts SJ (ed.), Veterinary Obestetric and Genital Diseases. Woodstock: published by the author; 1971:
170-173.

2. Jalakas M. Mummification of fetal membranes in the bovine vagina: a case report. Theriogenology 2000; 
54: 1281-1284.

3. Barth AD. Induced abortion in cattle. In: Morrow DA (ed.), Current Therapy in Theriogenology. Philadelphia: WB Saunders; 1986: 205.

4. Roberts SJ. The enigma of fetal mummification. J Am Vet Med Assoc 1962; 140: 691-698.

5. Stevens RW, King GJ. Genetic evidence for a lethal mutation in Holstein-Friesian cattle. J Heredity 1968; 59: 366-368.

6. Doran GH, Dickel DN, Ballinger WE, Agee OF, Laipis PJ, Hauswirth WW. Anatomical, cellular and molecular analysis of 8000- yr-old human brain tissue from the windover archaeological site. Nature 1986; 323: 803-806.

7. Paabo S. Molecular cloning of ancient Egyptian mummy DNA. Nature 1996; 314: 644-645.

8. Paabo S, Gifford JA, Wilson AC. Mitochondrial DNA sequences from a 7000-year old brain. Nucleic Acids Res 1998; 16: 9775-9787.

9. Krings M, Capelli C, Tschentscher F, Geisert H, Meyer S, von Haeseler A, Grossschmidt K, Possnert G, Paunovic M, Paabo S. A view of Neandertal genetic diversity. Nat Genet 2000; 26: 144-146.

10. Brush PJ, Anderson PH, Gunning RF. Identification of Factor XI deficiency in HolsteinFriesian cattle in Britain. Vet Rec 1987; 121: 14-17.

11. Kociba GD, Ratnoff OD, Loeb WF, Wall RL, Heider LE. Bovine plasma thromboplastin antecedent (Factor XI) deficiency. J Lab Clin Med
1969; 74: 37-41.

12. Gentry PA, Crane S, Lotz F. Factor XI (plasma thromboplastin antecedent) deficiency in cattle. Can Vet J 1975; 16: 160-163.

13. Marron BM, Robinson JL, Gentry PA, Beever JE. Identification of a mutation associated with factor XI deficiency in Holstein cattle. Anim Genet 2004; 35: 454-456.

14. Gentry PA, Overton KM, Robinson JL. Bovine Factor XI deficiency. Illinois Dairy Report 1996; pp. 32-35.

15. Evans HE, Sack WO. Prenatal development of domestic and laboratory mammals: growth curves, external features and selected references. Anat Hist Embryol 1973; 2: 11-45.

16. Sambrook J, Russell DW. Preparation and analysis of eukaryotic genomic DNA. In: Sambrook J, Russell DW (eds.), Molecular Cloning. New York: Cold Spring Harbor Laboratory Press; 2001: 6.1-6.5.

17. Salo WL, Aufderheide AC, Buikstra J, Holcomb TA. Identification of Mycobacterium tuberculosis DNA in a pre-Columbian Peruvian mummy. Proc Natl Acad Sci USA 1994; 91: 2091-2094.

18. Baszler TV, Gay LJ, Long MT, Mathison BA. Detection by PCR of Neospora caninum in fetal tissue from spontaneous bovine abortions. J Clin Microbiol 1999; 37: 4059-4064.

19. Mamone JT. A method for representatively amplifying genomic DNA. Genomic/Proteomic Technology 2003; April/May issue: 21-24. 